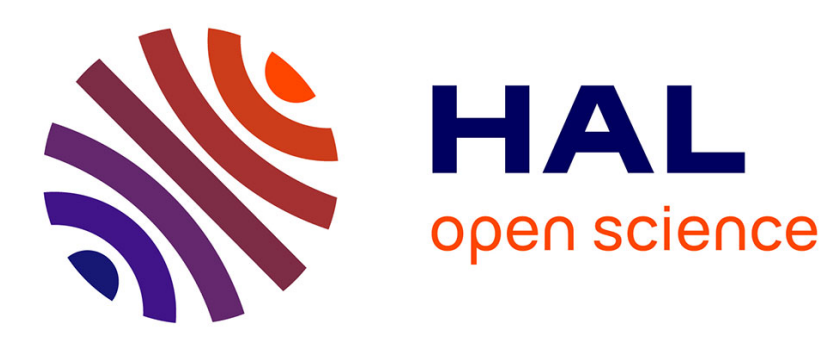

\title{
Expression, Purification, and Applications of the Recombinant Lectin PVL from Psathyrella velutina Specific for Terminal N-Acetyl-Glucosamine
}

Oriane Machon, Annabelle Varrot

\section{- To cite this version:}

Oriane Machon, Annabelle Varrot. Expression, Purification, and Applications of the Recombinant Lectin PVL from Psathyrella velutina Specific for Terminal N-Acetyl-Glucosamine. Lectin Purification and Analysis. Methods in Molecular Biology, pp.421-436, 2020, 10.1007/978-1-0716-0430-4_41 . hal02928046

\section{HAL Id: hal-02928046 \\ https://hal.science/hal-02928046}

Submitted on 30 Sep 2020

HAL is a multi-disciplinary open access archive for the deposit and dissemination of scientific research documents, whether they are published or not. The documents may come from teaching and research institutions in France or abroad, or from public or private research centers.
L'archive ouverte pluridisciplinaire HAL, est destinée au dépôt et à la diffusion de documents scientifiques de niveau recherche, publiés ou non, émanant des établissements d'enseignement et de recherche français ou étrangers, des laboratoires publics ou privés. 


\title{
Chapter 41
}

\section{Expression, Purification and Applications of the Recombinant Lectin PVL from Psathyrella velutina Specific for Terminal $N$-Acetyl-Glucosamine.}

\section{Oriane Machon and Annabelle Varrot*}

Univ. Grenoble Alpes, CNRS, CERMAV, 38000 Grenoble, France

*Corresponding author: Annabelle Varrot, annabelle.varrot@cermav.cnrs.fr

Running Head: Expression, purification and applications of the PVL lectin

\begin{abstract}
The lectin PVL from the mushroom Psathyrella velutina is the founding member of novel family of fungal lectins. It adopts a seven bladed $\beta$-propeller presenting six binding sites specific for the recognition of non-reducing terminal $N$-acetyl-glucosamine (GlcNAc). The latest can be mainly found in glycoconjugates presenting truncated glycans where aberrant $\beta$ GlcNAc terminated glycans represent tumor markers. It can also be found in $O$-GlcNAcylated proteins where disruption of the $O$-GlcNAcylation homeostasis is associated with many physiopathological states. The recombinant PVL lectin proved to be a very powerful tool for labelling terminal GlcNAc antigens displayed by extracellular glycoconjugates but also by $O$ GlcNAcylated proteins found in the cytoplasm and nucleus. This chapter will describe how to produce and purify recombinant PVL and several applications for $\mathrm{PVL}$ as probe for the detection of terminal $O$-GlcNAc.
\end{abstract}

Keywords: Terminal $O$-GlcNAc, tumor markers, $O$-GlcNAcylation detection, lectin probe, ELLA.

\section{Introduction}

Glycosylation is one of the most prominent and diverse form of posttranslational modification (PTM) of proteins and lipids. It is performed by an incredibly complex and dynamic biosynthetic machinery affected by scores of genetic and environmental factors. It results in a non-templated glycome, where glycans have a key role on mediating or modulating the function of their carriers. The glycome carries cell signatures of health and disease as glycosylation defects or alterations are commonly connected with physiopathological states such as cancers, chronic inflammatory diseases or infections [1].

$\mathrm{N}$-Acetyl-glucosamine (GlcNAc) is one of the major glycan moieties found in glycoconjugates of the extracellular matrix where it is usually $\beta$ linked and rarely exposed in terminal position on the surface of healthy 
tissues except in gastric mucosa where $\alpha 1,4-G l c N A c$ capped mucins, secreted by gland mucous cells, are exposed [2]. Truncated $\mathrm{N}$ - and $\mathrm{O}$ glycans and glycosphingolipids displaying aberrant non reducing terminal $\beta$-GlcNAc are considered as tumor markers: i.e. truncated core $3 O$ glycans (GlcNAc $\beta 1-3 \mathrm{GalNAc} \alpha-O-\mathrm{Ser} / \mathrm{Thr}$ ) in colorectal cancers [3]. A simple and distinct $O$-glycosylation called $O$-GlcNAcylation has been uncovered in the early 1980s [4]. It consists of the addition of a single GlcNAc to specific serine or threonine residues of cytoplasmic, nuclear and mitochondrial proteins. $O$-GlcNAcylation is ubiquitous in metazoans and widespread in living beings, where it plays a key role in the regulation of multiple cellular processes from epigenetics and stress response to cell signaling. It is a highly dynamic modification interplaying extensively with phosphorylation. Disturbance of $O$-GlcNAcylation homeostasis can be associated with the pathogenesis of many diseases such as diabetes, cancers, or Alzheimer disease (reviewed in $[5,6]$ ). GlcNAc is a small, noncharged, and labile moiety to be readily detectable by conventional mass spectrometry and gel electrophoresis. The detection of $O$-GlcNAcylation remains challenging, and the lack of efficient tools for this has hampered both the discovery and the study of this essential modification.

Several fungal lectins highly specific for non-reducing terminal GlcNAc epitope have been isolated from mushrooms. The first one, PVL (Psathyrella velutina lectin), has been isolated from Lacrymaria velutina formally known as $P$. velutina [7]. It is also able to recognize non-reducing terminal $N$-acetylneuraminic acid (Neu5Ac) residues but with lesser affinity [8]. The resolution of PVL structure uncovered a novel family of lectins characterized by a seven bladed $\beta$-propeller fold [9]. Only three fungal members have been structurally characterized to date: PVL, AANL (Agrocybe aegerita lectin 2 formerly called AAL2) and PAL ( $P$. asperospora lectin) [10-12]. Their structures in complex with GlcNAc gave the molecular basis for the recognition of terminal GlcNAc as well as those for terminal Neu5Ac in the case of PVL. Six binding sites in the form of a shallow pocket were identified at the interface between blades apart on the one involved in the Velcro closure of the propeller (Fig 1).

A signature motif was identified for this family (PropLec7B) that can now be used to predict new members to this family in translated genomes and sequence databases [13]. PVL and AANL can be produced in recombinant form without impairing their structure and recognition aptitudes [10, 11]. A clear avidity effect could be observed for rPVL where its affinity increases from $132 \mu \mathrm{M}$ for single binding event as observed for GlcNAc on PVL-coated sensor chip by surface plasmon resonance or in solution by isothermal microcalorimetry [10] to $60 \mathrm{nM}$ in the case of multivalent presentation of rPVL on GlcNAc- coated SPR chips [14]. Lectins from this family present therefore great potential in biomedical applications as reagent for the detection of terminal $O$-GlcNAc and for glycoconjugates 


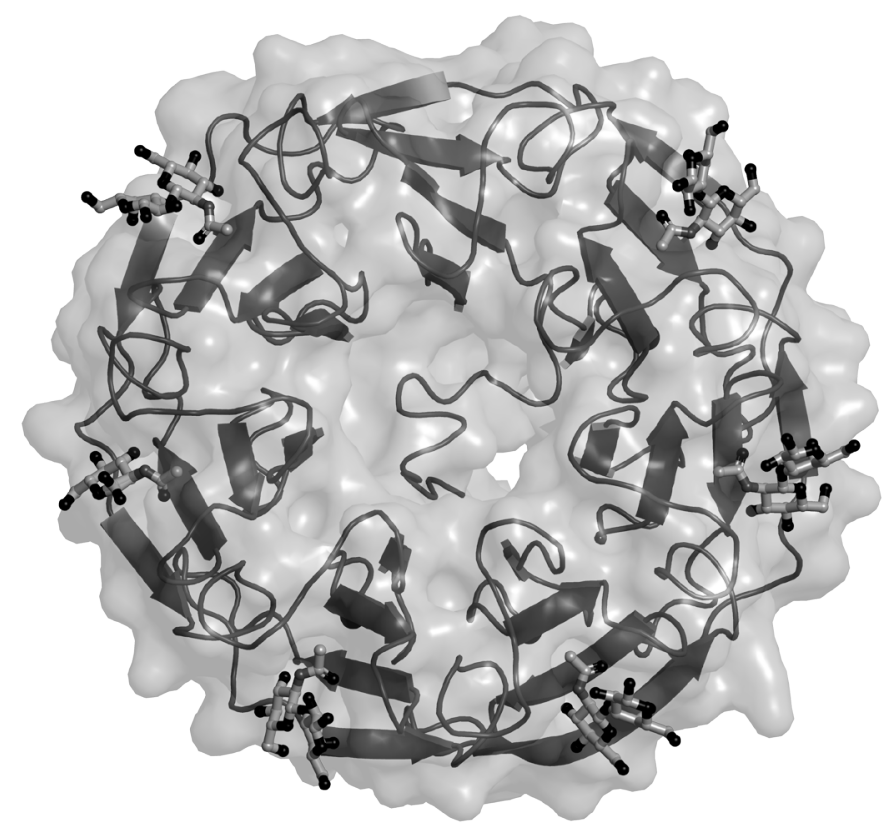

Fig 1: Surface and cartoon representation of the seven-bladed $\beta$-propeller of recombinant PVL in complex with GlcNAc- $\beta 1,3 \mathrm{Gal}$ disaccharide depicted in balls and sticks (PDB 4UP4).

separation $[8,15]$. rPVL can be conjugated with different molecules (fluorophore, biotin, or peroxidation) and proved to be a very powerful probe to label both truncated glycans on human cancer cells and tissues by FACS, immunofluorescence, or histochemistry [10] and GlcNAcylated proteins using western blot [14]. rPVL can also be used in enzyme-linked lectin assay (ELLA) to detect terminal GlcNAc in glycoconjugates. In this chapter, we will detail protocols used for the expression, purification of rPVL, as well as possible conjugation and its use in different detection methods.

\section{Materials}

Prepare all solutions using analytical grade reagents and ultrapure water and filter on $0.22 \mu \mathrm{M}$ membrane before usage. Follow waste disposal regulations.

\subsection{Production of $r P V L$}

1. pET25b-rPVL plasmid encoding for the PVL protein obtained according to previously published protocol [10].

2. Escherichia coli Tuner $^{\mathrm{TM}}(\mathrm{DE} 3)$ cells (Novagen-Merck).

3. Lennox L Broth Base (LB, Invitrogen). Dissolve $20 \mathrm{~g}$ in $1 \mathrm{~L}$ of distilled water and autoclave $20 \mathrm{~min}$ at $121^{\circ} \mathrm{C}$.

4. $100 \mathrm{mg} / \mathrm{mL}$ of ampicillin (Amp, culture grade sodium salt) in water.

5. $1 \mathrm{M}$ isopropyl- $\beta$-D-thiogalactopyranoside (IPTG).

6. $1 \mathrm{~L}$ polycarbonate centrifuge bottle (Nalgene) and $50 \mathrm{ml}$ sterile conical centrifuge tubes.

7. Centrifuge with adapted rotors. 


\subsection{Purification of $r P V L$}

1. $0.45 \mu \mathrm{m}$ polyethersulfone (PES) syringe filter.

2. C10/10 column with flow adapter (GE Healthcare Life Sciences) or empty Econo-Pac ${ }^{\circledR}$ Chromatography Columns (Bio-Rad).

3. LNT2 affinity resin, (GLY011-Gel, Elicityl, Crolles, France).

4. Endonuclease such as Benzonase or Denarase at 250 units $/ \mu \mathrm{L}$.

5. One Shot table top cell disruptor (Constant Systems Ltd).

6. Binding buffer: $20 \mathrm{mM}$ Tris- $\mathrm{HCl} \mathrm{pH} 7.5,150 \mathrm{mM} \mathrm{NaCl}$, and $100 \mu \mathrm{M}$ $\mathrm{CaCl}_{2}$.

7. Washing buffer: $20 \mathrm{mM}$ Tris- $\mathrm{HCl} \mathrm{pH} 7.5,1 \mathrm{M} \mathrm{NaCl}$, and $100 \mu \mathrm{M}$ $\mathrm{CaCl}_{2}$.

8. Elution buffer: $20 \mathrm{mM}$ Tris-HCl pH 7.5, $150 \mathrm{mM} \mathrm{NaCl}, 100 \mu \mathrm{M} \mathrm{CaCl}_{2}$ and $500 \mathrm{mM}$ GlcNAc (Carbosynth).

9. $12 \%$ SDS-PAGE gel with vertical gel electrophoresis unit and universal power supply.

10. Precision Plus Protein ${ }^{\mathrm{TM}}$ Unstained Standards (Bio-Rad Ltd).

11. Instant Blue ${ }^{\mathrm{TM}}$ (Expedeon).

12. Snakeskin dialysis tubing 3500 MWCO (Thermo Fisher Scientific).

\subsection{Hemagglutination Assays}

(HA)

1 U-shaped 96-well plates (Nunc, Rochester NY).

$24 \%$ rabbit erythrocytes in $150 \mathrm{mM} \mathrm{NaCl}$.

\subsection{Affinity Measurements}

by Surface Plasmon

Resonance (SPR)

1. Biacore X100 (GE Healthcare Life Sciences).

2. CM5 sensor chips (GE Healthcare Life Sciences).

1. Running buffer: PBS-Ca (phosphate buffered saline: $10 \mathrm{mM} \mathrm{Na}_{2} \mathrm{HPO}_{4}$, $1.76 \mathrm{mM} \mathrm{KH}_{2} \mathrm{PO}_{4}, 2.7 \mathrm{mM} \mathrm{KCl}, 137 \mathrm{mM} \mathrm{NaCl} \mathrm{pH} 7.4$ supplemented with $100 \mu \mathrm{M} \mathrm{CaCl}_{2}$ ) as running buffer. Dissolve one tablet (SigmaAldrich, ref P4417) in $200 \mathrm{~mL}$ of water.

3. Amine coupling kit (GE Healthcare Life Sciences).

4. Streptavidin from Streptomyces avidinii (Sigma-Aldrich) at 100 $\mu \mathrm{g} / \mathrm{mL}$ in $10 \mathrm{mM}$ sodium acetate $\mathrm{pH} 5.0$ for chip immobilization.

5. $1 \mathrm{M}$ ethanolamine for blocking the sensor surface.

6. $\beta$-D-GlcNAc-PAA-biotin and $\alpha$-L-fucose-PAA-biotin (Lectinity, Moscow).

7. GlcNAc (Carbosynth, UK).

\section{$2.5 \quad r P V L$ Labelling}

1. N,N-Dimethylformamide (DMF).

2. D-salt polyacrylamide desalting column $6 \mathrm{~K}$ (Pierce). 
3. Biotinamidohexanoyl-6-aminohexanoic acid N-hydroxysuccinimide ester (Sigma-Aldrich) for biotinylation.

4. EZ-Link ${ }^{\mathrm{TM}}$ Plus Activated Peroxidase kit (Thermo Fisher Scientific) for coupling with horseradish peroxidase.

5. Alexa Fluor ${ }^{\mathrm{TM}} 488$ NHS Ester (ref A20000) (Thermo Fisher Scientific) for coupling with fluorophore.

\subsection{Enzyme-Linked Lectin Assays}

(ELLA)

1. 96-well plates Microlon ${ }^{\circledR}$ (Greiner Bio-One).

2. Biotinylated rPVL.

3. PBS buffer $\mathrm{pH} 7.4$.

4. PBS-BSA: PBS supplemented with $0.1 \%(\mathrm{w} / \mathrm{v})$ Grade $\mathrm{V}$ bovine serum albumin (BSA, Sigma-Aldrich, ref A7030).

5. Tween 20 (Sigma-Aldrich).

6. PAA- $\beta-\mathrm{N}$-acetylglucosamine (Lectinity, Moscow).

7. Streptavidin-peroxidase (Sigma-Aldrich, ref S5512) and 3,3',5,5'tetramethylbenzidine (TMB, Thermo Fisher Scientific) for detection of biotinylated lectins.

8. TECAN SparkM10 plate reader.

\subsection{Western Blotting of $O$ -}

\section{GlcNAcylated Proteins}

1. Cell lines are obtained according to published protocol [14].

2. Lysis buffer: $10 \mathrm{mM}$ Tris/ $\mathrm{HCl} \mathrm{pH} 7.4,150 \mathrm{mM} \mathrm{NaCl}, 1 \mathrm{mM}$ EDTA, $1 \%(\mathrm{v} / \mathrm{v})$ Triton X-100, $0.5 \%(\mathrm{w} / \mathrm{v})$ sodium deoxycholate, $0.1 \%(\mathrm{w} / \mathrm{v})$ SDS and protease inhibitors.

3. $10 \%$ SDS-PAGE gel with Mini-PROTEAN® Tetra electrophoresis system, Mini Trans-Blot® Cell, and universal power supply (Bio-Rad Ltd).

4. Nitrocellulose membrane (GE Healthcare Life Sciences).

5. Ponceau S (Sigma-Aldrich).

6. Grade V BSA for membrane saturation.

7. Tris buffered saline (TBS)-Tween buffer: $15 \mathrm{mM}$ Tris/HCl, $140 \mathrm{mM}$ $\mathrm{NaCl}$ and $0.05 \%(\mathrm{v} / \mathrm{v})$ of Tween 20 (Sigma Aldrich), $\mathrm{pH}$ 8.0.

8. HRP-labelled rPVL at $1 \mathrm{mg} / \mathrm{mL}$ in TBS.

9. Chemiluminescence imaging (Fusion Solo system, Vilber Lourmat Collegien).

\subsection{Immunofluorescence Analysis} on Whole Cells

1. Cells lines cultured according to recommended protocols.

2. Four-chamber culture slides.

3. Ice-cold PBS buffer $\mathrm{pH}$ 7.4. 
4. Paraformaldehyde and BSA.

5. Alexa Fluor 488 labelled rPVL at $5 \mu \mathrm{g} / \mathrm{mL}$ in PBS-BSA $2 \%$.

6. BX41 microscope equipped with a DP-70 digital camera system (Olympus, Tokyo, Japan).

7. Pseudo-confocal microscope ApoTome equipped with AxioCam $\operatorname{MRm}(\mathrm{N} / \mathrm{B})$.

\subsection{Immuno-histochemistry}

1. Fixed tissue sections.

2. Biotinylated rPVL at $0.7 \mu \mathrm{g} / \mathrm{mL}$.

3. $3 \%(\mathrm{v} / \mathrm{v})$ hydrogen peroxide or $5 \%(\mathrm{w} / \mathrm{v})$ bovine serum albumin in PBS buffer.

4. Streptavidin at $0.1 \mathrm{mg} / \mathrm{mL}$ and biotin at $0.5 \mathrm{mg} / \mathrm{mL}$.

5. Streptavidin-peroxidase.

6. HRP detection kit (DAB, Ventana Medical Systems or AEC, Vector Laboratories).

7. Mayer's hematoxylin solution (Merck, Whitehouse Station, NJ).

8. Sialidase (New England Biolabs) and $\beta-D-N$-acetylhexosaminidase.

9. BX41 microscope equipped with a DP-70 digital camera system (Olympus, Tokyo, Japan) or NanoZoomer slide scanner (Hamamatsu, Hamamatsu City).

\section{Methods}

All measurements are done at room temperature $\left(22^{\circ} \mathrm{C}\right)$ unless otherwise stated. The protein concentration was verified by measuring optical density at $280 \mathrm{~nm}$ by using a theoretical extinction coefficient of 65,890 $\mathrm{M}^{-1} \mathrm{~cm}^{-1}$ and a molecular weight of $42974 \mathrm{Da}$ and a NanoDrop 2000 (Thermo Fisher Scientific).

\subsection{Production of $\mathrm{PPVL}$}

1. Inoculate $1 \mathrm{~L}$ of $\mathrm{LB}$ media supplemented with $100 \mu \mathrm{g} / \mathrm{mL}$ of ampicillin with $30 \mathrm{~mL}$ of an overnight preculture of Escherichia coli Tuner $^{\mathrm{TM}}$ (DE3) cells harboring the pET25b-rPVL, plasmid and place in an incubation shaker at $160 \mathrm{rpm}$ and $37^{\circ} \mathrm{C}$.

2. Grow the cells until an $\mathrm{OD}_{600}$ of 0.6 and switch the incubator temperature to $16^{\circ} \mathrm{C}$.

3. When the culture reached an $\mathrm{OD}_{600}$ of 0.8 , induce $\mathrm{PPVL}$ expression by adding IPTG at a final concentration of $0.1 \mathrm{mM}$.

4. Culture the cells overnight for at least $16 \mathrm{~h}$ at $160 \mathrm{rpm}$.

5. Harvest the cells by 10 min centrifugation at 5,000 $\times g$.

6. Transfer the cells in a sterile $50 \mathrm{~mL}$ plastic tube and weight the cell pellet (see Note 1). 


\subsection{Purification of $r P V L$}

1. Resuspend the cell pellet with cold binding buffer at the rate of $5 \mathrm{~mL}$ of binding buffer per gram of wet cells using a vortex.

2. Add $1 \mu \mathrm{L}$ of endonuclease and incubate on a rotating wheel for $30 \mathrm{~min}$.

3. Lyse the cells using the One Shot cell disruptor at a pressure of 1.9 kbars (see Note 2).

4. Clarify the sample by centrifugation at $24,000 \times \mathrm{g}$ and $4{ }^{\circ} \mathrm{C}$ for $30 \mathrm{~min}$.

5. Filter the supernatant using a $0.45 \mu \mathrm{M}$ PES syringe filter.

6. Load the filtered supernatant on $2 \mathrm{~mL}$ Toyopearl-LnT2 resin (Elicityl, Crolles France, see Note 3) equilibrated with binding buffer for purification by affinity chromatography and apply binding buffer until $\mathrm{OD}_{280 \mathrm{~nm}}$ reaches a baseline. Collect fractions of $15 \mathrm{~mL}$.

7. Wash unspecifically bound proteins with 10 column volumes (CVs) of washing buffer and then $5 \mathrm{CVs}$ of binding buffer.

8. Elute with $10 \mathrm{CVs}$ of elution buffer and collect fractions of $1 \mathrm{~mL}$.

9. Analyze fractions of each step by gel electrophoresis on $12 \%$ SDSPAGE gel after adding denaturing loading buffer to each fraction aliquots and heating at $100{ }^{\circ} \mathrm{C}$ for $5 \mathrm{~min}$. Load $10 \mu \mathrm{L}$ of fraction as well as protein standards prior running the gel at $200 \mathrm{~V}$ in Tris-glycine buffer. Unpack the gel and rinse it with water prior coloration with 10 $\mathrm{mL}$ of Instant Blue ${ }^{\mathrm{TM}}$ for $1 \mathrm{~h}$ under low shaking. Rinse and store the gel in water (Fig. 2).

10. Pool fractions containing $>95 \%$ pure protein and dialyze extensively against PBS buffer supplemented with $100 \mu \mathrm{M} \mathrm{CaCl}_{2}$ for 7 days prior storage at $4{ }^{\circ} \mathrm{C}$ (see Note 4$)$.

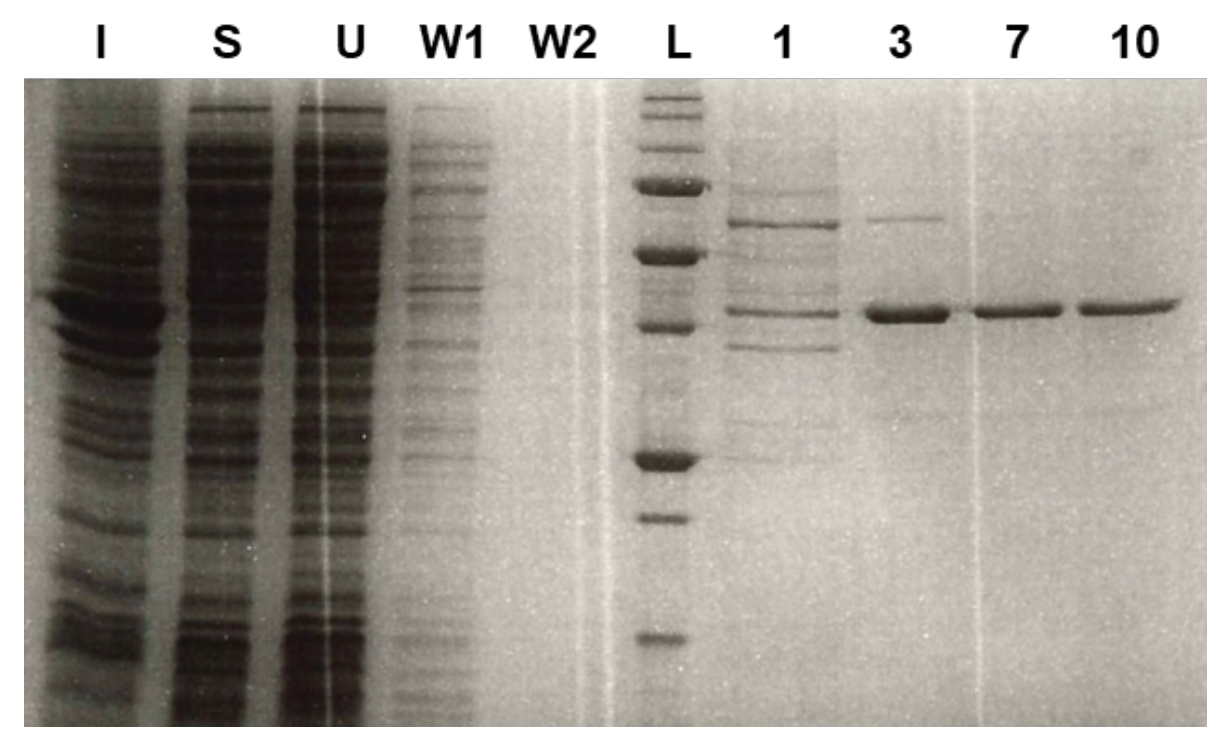

Fig 2: $12 \%$ SDS-PAGE gel electrophoresis of rPVL purification. I: Insoluble fraction, S: soluble fraction, FT: unbound fraction, W1: wash with equilibration buffer, W2: fraction for washing step with $1 \mathrm{M} \mathrm{NaCl}, \mathrm{L}$ : ladder, 1-10: eluted fractions. Ladder is 250, 150, 100, 75, 50, 37, 25, 20 and $15 \mathrm{kDa}$ from top to bottom. 


\subsection{Hemagglutination Assays}

(HA)

Hemagglutination permits to check rapidly the binding activity of rPVL and its ability to attach to surface glycoconjugates of the red blood cells. Non-agglutinating cells will sediment at the bottom of the well and form a red button, while agglutinating cells will form a diffuse network preventing the cells' sedimentation.

1. Dilute rabbit erythrocytes $(\mathrm{RBC})$ to a $4 \%$ solution in $150 \mathrm{mM} \mathrm{NaCl}$.

2. Deposit $25 \mu \mathrm{L}$ of $150 \mathrm{mM} \mathrm{NaCl}$ in a 96 -well plate.

3. Deposit $25 \mu \mathrm{L}$ of rPVL at $1 \mathrm{mg} / \mathrm{mL}$ in the first well and perform a twofold dilution series.

4. Add $50 \mu \mathrm{L}$ of $4 \% \mathrm{RBCs}$ and incubate $1 \mathrm{~h}$.

5. Determine hemagglutination unit (HAU) as the minimum concentration of lectin required to observe hemagglutination (see Note 5).

6. Use $150 \mathrm{mM} \mathrm{NaCl}$ as negative control and lectin known to hemagglutinate as positive control.

\subsection{Affinity Measurements by SPR}

Surface plasmon resonance (SPR) experiments allow to monitor the interaction between two molecules in real time. In a flow channel, one partner (ligand) is immobilized on a biosensor chip and the other (analyte) is passing over the ligand surface. All experiments were performed on a Biacore X100 (GE Healthcare Life Sciences) at $25^{\circ} \mathrm{C}$ in PBS-Ca as running buffer at a flow rate of $30 \mu \mathrm{L} / \mathrm{min}$.

1. Activate two channels by injecting $340 \mu \mathrm{L}$ of a fresh mixture of EDC/NHS for $400 \mathrm{~s}$ using a classical amine coupling procedure.

2. Inject streptavidin for $500 \mathrm{~s}$.

3. Inactivate remaining reacting species by injecting $240 \mu \mathrm{L}$ of $1 \mathrm{M}$ ethanolamine for $400 \mathrm{~s}$.

4. Immobilize biotinylated PAA- $\beta$-GlcNAc at $200 \mu \mathrm{g} / \mathrm{mL}$ for $10 \mathrm{~min}$ on channel 2 (see Note 6).

5. Inject rPVL on both channels in series of two-fold dilutions between 0 and $2 \mu \mathrm{M}(140 \mu \mathrm{L}$, dissociation: $400 \mathrm{~s})$.

6. Regenerate the chip after each injection with $0.5 \mathrm{M}$ GlcNAc in water for $30 \mathrm{~s}$.

7. Evaluate the data by using the Biacore X100 evaluation software and measure binding as resonance units over time after blank subtraction. Determine the dissociation constant by plotting response at equilibrium against analyte concentration (Fig. 3).

8. Perform at least duplicates. 


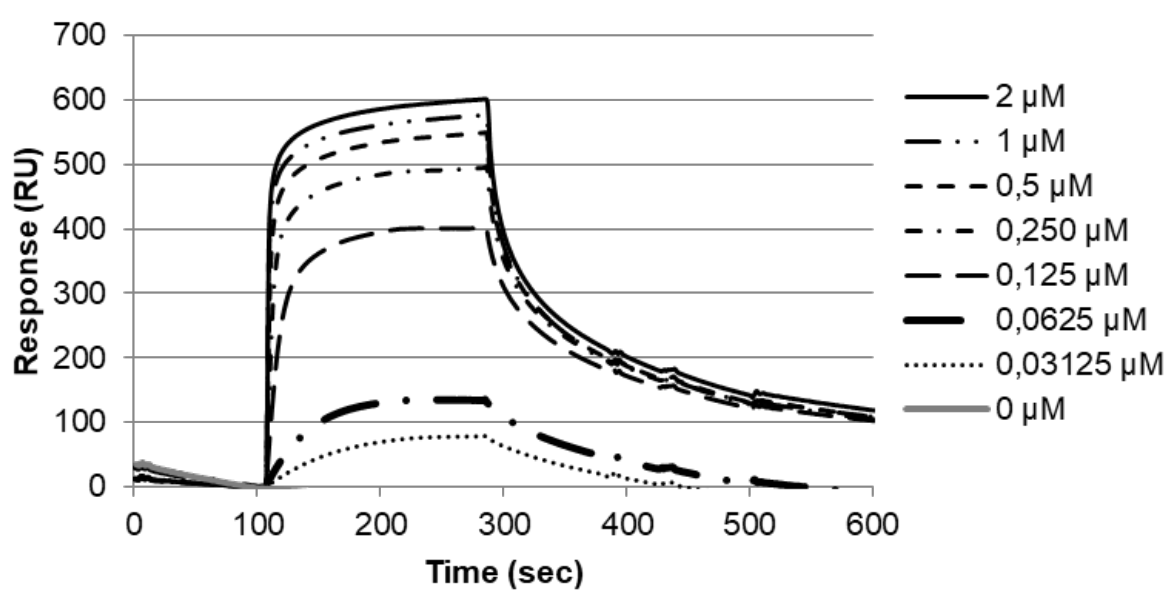

Fig 3: Sensorgrams for the interaction of rPVL (various concentrations) injected on a CM5 chip coated with streptavidin/biotin-PAA- $\beta-D-G l c N A c$ leading here to an $\mathrm{K}_{\mathrm{d}}$ of $42 \mathrm{nM}$ after steady state analysis.

\section{5 rPVL Labelling}

All reactions are done at room temperature using essentially manufacturer instructions. Unbound label is separated from labelled rPVL and buffer is exchanged to $\mathrm{PBS}+100 \mu \mathrm{M} \mathrm{CaCl}_{2}$ using a D-salt polyacrylamide desalting column $6 \mathrm{~K}$ (see Note 7). Fractions of $500 \mu \mathrm{L}$ are collected and their optical density is measured at $280 \mathrm{~nm}$. Labelled rPVL is stored at -20 ${ }^{\circ} \mathrm{C}$ in aliquots of $250 \mu \mathrm{L}$.

\subsubsection{Biotinylation}

1. Prepare a solution of biotinamidohexanoyl-6-aminohexanoic acid $N$ hydroxysuccinimide ester at $100 \mathrm{mM}$ in DMF.

2. Add $6 \mathrm{mmol}$ of biotin-NHS-ester to a solution of $10 \mathrm{mg} / \mathrm{mL}$ of $\mathrm{rPVL}$ in PBS buffer pH 7.4 (see Note 8). The volume added $(\mu \mathrm{L})$ is calculated according to the following equation:

$$
V=\frac{m_{\text {protein }}(\mathrm{mg}) \times 6 \mathrm{mmol}}{M_{\text {protein }}\left(\frac{\mathrm{g}}{\mathrm{mol}}\right)} \times \frac{1000000}{100 \mathrm{mM}}
$$

3. Incubate 30 min under agitation.

\subsubsection{HorseRadish \\ Peroxidase Coupling}

1. Reconstitute $1 \mathrm{mg}$ of lyophilized EZ-Link Plus Activated Peroxidase with $100 \mu \mathrm{L}$ of ultrapure water to obtain a solution at $10 \mathrm{mg} / \mathrm{mL}$.

2. Prepare rPVL at $1 \mathrm{mg} / \mathrm{mL}$ in PBS buffer $\mathrm{pH} 7.4$ (see Note 9).

3. Incubate $1 \mathrm{~mL}$ of $\mathrm{rPVL}$ with $100 \mu \mathrm{L}$ of HRP solution for $1 \mathrm{~h}$.

4. Add $10 \mu \mathrm{L}$ of sodium cyanoborohydride to the reaction in the fume hood, and incubate at room temperature for $15 \mathrm{~min}$.

5. Add $20 \mu \mathrm{L}$ of quenching buffer and incubate for $15 \mathrm{~min}$. 


\subsubsection{Alexa Fluor 488 \\ Coupling}

1. Prepare a solution of Alexa Fluor 488 NHS Ester at $10 \mathrm{mg} / \mathrm{mL}$ in DMF (see Note 10).

2. Prepare a solution of $\mathrm{rPVL}$ at $10 \mathrm{mg} / \mathrm{mL}$ in $50 \mathrm{mM}$ sodium bicarbonate buffer $\mathrm{pH} 9.7$.

3. Add $100 \mu \mathrm{L}$ of reactive compound to $1 \mathrm{~mL}$ of $\mathrm{rPVL}$ drop by drop while stirring.

4. Incubate for 1 hour under constant stirring.

5. Calculate the degree of labelling (DOL) according to the following formula after correcting the protein concentration at $280 \mathrm{~nm}$ for the contribution of the dye $\left(A_{\text {prot }}=A_{280}-A_{495} \times 0.11\right)$ :

$$
\text { DOL }=\frac{A_{495 n m} \times M W_{\text {protein }}}{[\text { protein }] \times 71000}
$$

\subsection{Enzyme-Linked Lectin Assay}

1. Prepare 96 -well plates by incubating $100 \mu \mathrm{L}$ of $5 \mu \mathrm{g} / \mathrm{mL}$ solution of $\beta$-GlcNAc-PAA diluted in PBS buffer $\mathrm{pH} 7.4$ overnight at room temperature (see Note 11).

2. Wash thrice the plate with $200 \mu \mathrm{L} /$ well of PBS.

3. Saturate wells by $200 \mu \mathrm{L} /$ well of $2 \%(w / v)$ BSA in PBS for $1 \mathrm{~h}$ at 37 ${ }^{\circ} \mathrm{C}$.

4. Wash five times the plate with $200 \mu \mathrm{L} /$ well PBS-Tween $200.05 \%$ and washes are repeated between each step until the end of the assay.

5. Dilute biotinylated rPVL in PBS-BSA in a range from 0 to 1000 $\mathrm{ng} / \mathrm{well}$.

6. Deposit $100 \mu \mathrm{L} /$ well and incubate it for $2 \mathrm{~h}$ at room temperature.

7. Add $100 \mu \mathrm{L} /$ well of $0.25 \mu \mathrm{g} / \mathrm{mL}$ of streptavidin-peroxidase diluted in PBS-BSA.

8. Incubate for $25 \mathrm{~min}$ at room temperature.

9. Wash the plate and reveal with $100 \mu \mathrm{L} /$ well of $3,3^{\prime}, 5,5^{\prime}-$ tetramethylbenzidine.

10. Stop the revelation by addition of $100 \mu \mathrm{L} /$ well of $0.1 \mathrm{M}$ of hydrogen chloride.

11. Read the optical density at $450 \mathrm{~nm}$ with a plate reader.

\subsection{Western Blotting of $O$ - \\ GlcNAcylated Proteins}

1. Lyse cell lines with lysis buffer.

2. Deposit equal amounts of protein on $10 \%$ SDS-PAGE under reducing conditions.

3. Electroblot the gel on nitrocellulose using Mini Trans-Blot ${ }^{\circledR}$ Cell for $1 \mathrm{~h}$ at $100 \mathrm{~V}$ in cold transfer buffer (see Note 12). 
4. Color the nitrocellulose with Ponceau red staining to verify efficiency of the transfer and equal loading (see Note 12).

5. Saturate the membrane for 45 min with $4 \%(w / v)$ Grade V BSA in TBS-T (see Note 12).

6. Deposit HRP-rPVL 1:5,000 for $1 \mathrm{~h}$ at $4{ }^{\circ} \mathrm{C}$ (see Note 12).

7. Wash the membrane three times with TBS-T for 10 min each.

8. Use chemiluminescence imaging to reveal the membrane.

\subsection{Immunofluorescence Analysis on Whole Cells}

1. Inoculate four-chamber culture slides with $4 \times 10^{4}$ cells per chamber for $24 \mathrm{~h}$.

2. Wash the cells with ice-cold PBS.

3. Fix the cells with $2 \%$ paraformaldehyde for $10 \mathrm{~min}$ at $4^{\circ} \mathrm{C}$.

4. Wash three times with cold PBS for 5 min each.

5. Saturate slides with $1 \%(\mathrm{w} / \mathrm{v})$ BSA in PBS.

6. Wash again three times with cold PBS for 5 min each.

7. Deposit rPVL-Alexa488 on the cells to stain them (Fig. 4, see Note 13).

8. Examine cells with BX41 microscope and a pseudo-confocal microscope ApoTome.

MDA-MB-231

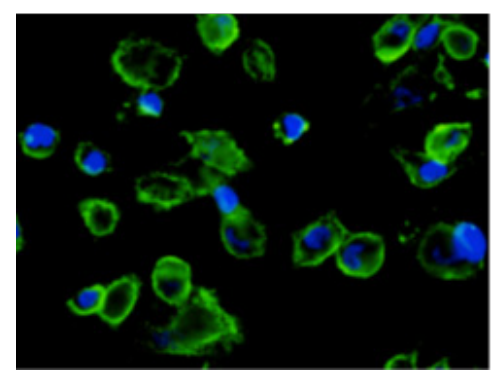

H358

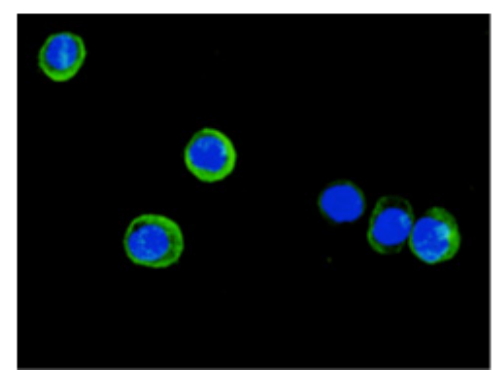

H441

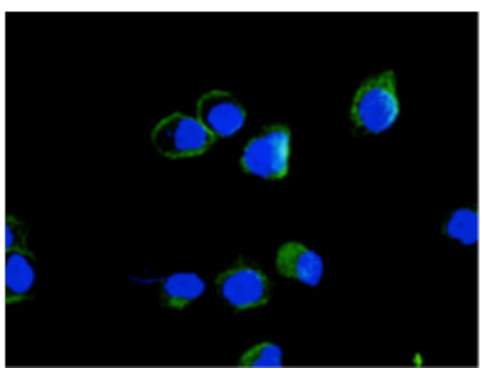

Fig. 4: Merge microscopy images of cancer cells treated for 30 min at $37^{\circ} \mathrm{C}$ with $5 \mu \mathrm{g} / \mathrm{mL}$ rPVL labelled with Alexa Fluor 488. Blue channel shows nuclei labeled with DAPI staining and green channel shows rPVL-Alexa Fluor 488. Human cancer cell lines: MDAMB-231: derived from metastatic site of mammary gland/breast, H358: derived from bronchioalveolar carcinoma and non-small cell lung cancer, and H441: derived from papillary adenocarcinoma.

\subsection{Immuno histochemistry}

1. Deparaffinize tissue sections (see Note 14).

2. Block endogenous peroxidases by adding $3 \%(\mathrm{v} / \mathrm{v})$ hydrogen peroxide in PBS for 5 min (see Note 15).

3. Saturate sections with $5 \%(\mathrm{w} / \mathrm{v}) \mathrm{BSA}$ in PBS for $30 \mathrm{~min}$.

4. Deposit biotinylated $\mathrm{rPVL}$ at $0.7-1 \mu \mathrm{g} / \mathrm{mL}$ for $1 \mathrm{~h}$ at room temperature for ethanol-fixed sections or $2 \mu \mathrm{g} / \mathrm{mL}$ for formalin-fixed sections and wash it twice with PBS. 
5. Add indirect biotin-streptavidin system, and use the corresponding detection kit according to the manufacturer's instructions (see Note 16).

6. Wash the developed slides twice with PBS.

7. Perform counterstaining using hematoxylin.

8. Wash with water, dehydrate, and mount the sections.

9. Observe the sections with BX41 microscope or imaged with a NanoZoomer slide-scanner (Fig. 5).

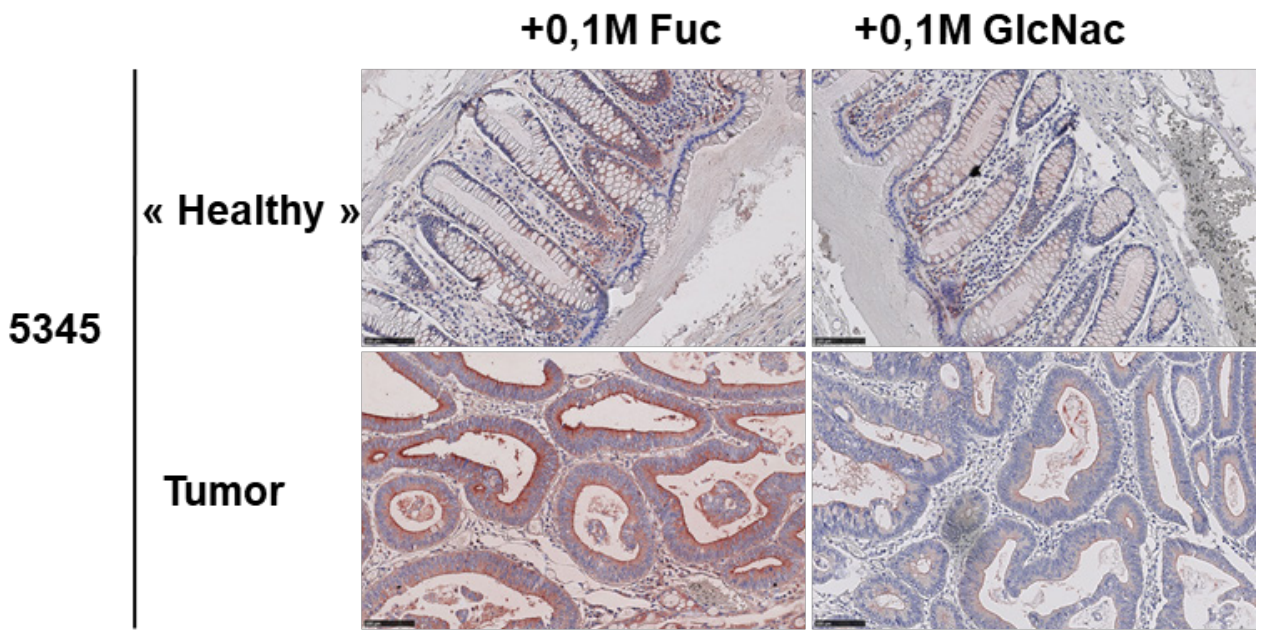

Fig. 5: Labelling of tumoral tissues with rPVL. Colon sections of tumoral or adjacent tissue obtained from tumor surgical resections before the law 88-138 of December 20, 1988 from patients \# 5345 stained with $1 \mu \mathrm{gml}-1 \mathrm{rPVL}-\mathrm{biot}$ in the presence of $0.1 \mathrm{M}$ fucose or $0.1 \mathrm{M}$ GlcNAc followed by streptavidinHRP. Slides were imaged using a NanoZoomer slide scanner with a 20x magnification. Image partly reproduced from [10].

\section{Notes}

1. Cells can be resuspended in some LB prior transfer in the preweighted $50 \mathrm{ml}$ sterile conical centrifuge tube and centrifugation for $10 \mathrm{~min}$ at $5,000 \times g$. Remove the supernatant and weight the cell pellet. The cell pellet can be stored at $-20{ }^{\circ} \mathrm{C}$ or $-80{ }^{\circ} \mathrm{C}$ if the purification cannot be done immediately.

2. Cell lysis can also be performed with a French press or by sonication on ice. In the latter case, 0.5 pulses are recommended for six periods of $30 \mathrm{~s}$ at $250 \mathrm{~W}$ spaced with a rest time of 1 minute on ice in between to avoid overheating and protein denaturation.

3. Pack resin in empty chromatography column and use an automated purification system to improve purification yield by allowing a longer contact time with the matrix (flowrate of 0.5 to $1 \mathrm{~mL} / \mathrm{min}$ ). $9 \mathrm{mg}$ of rPVL can be purified for $1 \mathrm{ml}$ of resin with automated system compare to only $3 \mathrm{mg}$ when gravity is used. If gravity is used, reapply the sample three times to the column prior elution. Most GlcNAc affinity matrix tested was not recognized by rPVL apart from the GlcNAc Gel 
(EY, USA, ref CG-003-5) but it has been unavailable for many months. The yield of purification was however much lower and we usually purified only $1 \mathrm{mg}$ of rPVL per $\mathrm{mL}$ of gel. Chitin matrix has been originally used for the native protein [7], but binding of rPVL proved to be very poor on that matrix that led to very big and dilute sample. The LNT2 matrix has been developed especially for the purification of rPVL.

4. rPVL is stable in PBS $+\mathrm{CaCl}_{2}$ for several weeks at $4{ }^{\circ} \mathrm{C}$ but it is recommended to centrifuge the sample prior use. For long term storage, dialyze the protein against ultrapure water prior freeze-drying and storage at $-20{ }^{\circ} \mathrm{C}$. To avoid precipitation due to the brutal change from buffer to water, rPVL should be dialyzed first against a buffer containing $50-100 \mathrm{mM} \mathrm{NaCl}$ and $100 \mu \mathrm{M} \mathrm{CaCl}_{2}$ for 3 days and then against ultrapure water for another 3 days. $\mathrm{CaCl}_{2}$ seems to have a structural role that is why it is added to all buffers, but it is not implicated in the binding of ligands. It should not be removed immediately from the dialysis buffer.

5. Hemagglutination inhibition assays (HIA) with GlcNAcylated ligands can also be performed. $25 \mu \mathrm{l}$ of two-fold diluted ligand in $150 \mathrm{mM}$ $\mathrm{NaCl}$ was incubated for $60 \mathrm{~min}$ at room temperature (RT) with $25 \mu \mathrm{L}$ of rPVL at a concentration equal to two HAU prior addition of $50 \mu \mathrm{L}$ of $4 \%$ RBC. Reading was performed after $1 \mathrm{~h}$ at room temperature and the HA inhibitory titer is defined as the concentration of inhibitor necessary for complete inhibition of hemagglutination.

6. Use a low density chip to avoid mass transport. A low density chip is obtained by immobilizing a mixture of $10 \%$ recognized carbohydrate ( $\beta$-D-GlcNAc-PAA-biotin) and 90\% non-bound carbohydrate $(\alpha-\mathrm{L}$ Fuc-PAA-biotin) to 270 resonance unit (RU). A reference surface with non-bound carbohydrate is present in flow channel 1, thus allowing for subtraction of bulk effects and non-specific interactions with unbound carbohydrate (same as previously, $\alpha$-L-Fuc-PAA-biotin). This chip will permit to measure avidity (multivalent binding) of rPVL. The chip can also be prepared with other oligosaccharides such as sialylated one but a weaker biding will be observed [14]. To get monovalent affinity, a rPVL chip should be made where 3500 RU of rPVL $(100 \mu \mathrm{g} / \mathrm{mL}$ in $10 \mathrm{mM}$ sodium acetate $\mathrm{pH}$ 6.2) is immobilized using standard procedure for amine coupling on flow channel 2 and where flow channel 1 has only been activated and deactivated. In this case, two fold cascade dilutions of oligosaccharides are then injected on both channels. Similar procedure has been used for PAL and AANL $[11,12]$. Affinity can also be measured in solution by isothermal microcalorimetry as described in [10].

7. The use of polyacrylamide based desalting gel is favored to classical Sephadex G-25 such as PD-10 based on dextran (GE Healthcare Life 
Sciences). It will limit weak recognition or unspecific interactions with the sugar based matrix as observed for some lectins.

8. For coupling using primary amine, avoid buffers containing primary amines such as Tris, glycine, and ammonium salts.

9. The use of carbonate-bicarbonate buffer $\mathrm{pH} 9.4$ is usually recommended as it improves the efficacy of HRP conjugation, but the reaction worked well in PBS for rPVL.

10. Resuspend the Alexa Fluor 488 in DMF just before use and use immediately since the compound in not stable in solution. A ratio of 1 $\mathrm{mg}$ of compound for $10 \mathrm{mg}$ of protein has been used. Other fluorophores such as Alexa Fluor 680 can also be used.

11. $500 \mathrm{ng} /$ well of antibodies or glycosylated protein to be analyzed can also be immobilized overnight. Use a commercial antibody first such as human IgG1 kappa (Sigma-Aldrich) to do a dilution range of rPVL from 0 to $1000 \mathrm{ng} /$ well and determine which concentration of rPVL to use for further experiments. The concentration giving half signal is chosen since it gives enough signal to differentiate the quantity of terminal GlcNAc on glycosylated proteins without saturation (65 ng/well has often been used to perform ELLA on antibodies).

12. Semi-dry transfer can also be performed. During wet transfer, keeping the transfer buffer cold is essential and could be done by adding a cooling unit or running it in a cold room. Preparing the SDS-PAGE gel the day before usually leads to better transfer. The use of a prestained protein ladder such as the Dual Color Standards (Bio-Rad Ltd) could replace the Ponceau red staining step. The membrane can be blocked either by BSA or milk. Biotinylated-rPVL (starting concentration of $0.6 \mathrm{mg} / \mathrm{mL}$ ) followed by an incubation with HRPavidin (dilution of 1:10,000) can also be used but the labelling is less specific due to the recognition of other biotinylated proteins. A mouse monoclonal anti-O-GlcNAc (R2, VWR, Fontenay-sous-Bois) can be used according to published protocol but labelling with HRP-rPVL is more efficient [14].

13. rPVL labelled with Alexa Fluor 488 or other fluorophores can also be used for flow cytometry experiments on cancer cell lines where the glycosylation is or not inhibited as described in [10].

14. Follow ethics statements on tissue sections. Required consent or certification should be obtained as well as their use approval by a Research Ethics Committee when necessary.

15. At this point, tissues sections can also be treated with $50 \mathrm{U}$ of sialidase (New England Biolab) for $2 \mathrm{~h}$ at $37^{\circ} \mathrm{C}$ to limit noise from recognition of sialylated oligosaccharides. $25 \mathrm{U}$ of $\mathrm{B}-\mathrm{D}-\mathrm{N}$-acetylhexosaminidases can also be used in similar conditions to confirm that the labelling is dependent of GlcNAc recognition. Add then fresh enzymes prior overnight incubation at $37^{\circ} \mathrm{C}$. Slides treated with the enzyme buffer 
were used as control. Inhibition of binding can be done by adding 100 $\mathrm{mM}$ GlcNAc at the same time than the labelled protein.

16. HRP-conjugated avidin D (Vector Laboratories, Burlingame, CA) diluted in $1 \%$ BSA in PBS can be used with detection, thanks to the addition of 3-amino-ethyl-carbazole (AEC kit; Vector Laboratories, Burlingame, CA) to the slides.

\section{Acknowledgments}

This work has been supported by CDP GLYCO@ALPS (ANR-15-IDEX02). Thanks to Jacques Le Pendu for permission to use the histochemistry figures.

\section{References}

1. Reily C, Stewart TJ, Renfrow MB, \& Novak J (2019) Glycosylation in health and disease. Nat Rev Nephrol, 15:346.

2. Ishihara K, Kurihara M, Goso Y, Urata T, Ota H, Katsuyama T, \& Hotta K (1996) Peripheral alpha-linked $\mathrm{N}$-acetylglucosamine on the carbohydrate moiety of mucin derived from mammalian gastric gland mucous cells: epitope recognized by a newly characterized monoclonal antibody. Biochem J 318(Pt 2):409-416.

3. Pedersen JW, Blixt O, Bennett EP, Tarp MA, Dar I, Mandel U, Poulsen SS, Pedersen AE, Rasmussen S, Jess P, Clausen H, \& Wandall HH (2011) Seromic profiling of colorectal cancer patients with novel glycopeptide microarray. Int J Cancer 128(8):1860-1871.

4. Torres CR \& Hart GW (1984) Topography and polypeptide distribution of terminal Nacetylglucosamine residues on the surfaces of intact lymphocytes. Evidence for O-linked GlcNAc. J Biol Chem 259(5):3308-3317.

5. Yang X \& Qian K (2017) Protein O-GlcNAcylation: emerging mechanisms and functions. Nat Rev Mol Cell Biol 18(7):452-465.

6. Zachara N, Akimoto Y, \& Hart GW (2017) The O-GlcNAc Modification. In: Varki A, Cummings RD, Esko JD, Stanley P, Hart GW, Aebi M, Darvill AG, Kinoshita T, Packer $\mathrm{NH}$ et al (eds) Essentials of glycobiology. Cold Spring Harbor Laboratory Press, Cold Spring Harbor, NY, pp 239-251

7. Kochibe N \& Matta KL (1989) Purification and properties of an N-acetylglucosaminespecific lectin from Psathyrella velutina mushroom. J Biol Chem 264(1):173-177.

8. Ueda H, Kojima K, Saitoh T, \& Ogawa H (1999) Interaction of a lectin from Psathyrella velutina mushroom with $\mathrm{N}$-acetylneuraminic acid. FEBS Lett 448(1):75-80.

9. Cioci G, Mitchell EP, Chazalet V, Debray H, Oscarson S, Lahmann M, Gautier C, Breton C, Perez S, \& Imberty A (2006) Beta-propeller crystal structure of Psathyrella velutina lectin: an integrin-like fungal protein interacting with monosaccharides and calcium. J Mol Biol 357(5):1575-1591.

10. Audfray A, Beldjoudi M, Breiman A, Hurbin A, Boos I, Unverzagt C, Bouras M, Lantuejoul S, Coll JL, Varrot A, Le Pendu J, Busser B, \& Imberty A (2015) A recombinant fungal lectin for labeling truncated glycans on human cancer cells. PLoS ONE 10(6):e0128190.

11. Ren XM, Li DF, Jiang S, Lan XQ, Hu Y, Sun H, \& Wang DC (2015) Structural basis of specific recognition of non-reducing terminal N-acetylglucosamine by an Agrocybe aegerita lectin. PLoS ONE 10(6):e0129608. 
12. Ribeiro JP, Ali Abol Hassan M, Rouf R, Tiralongo E, May TW, Day CJ, Imberty A, Tiralongo J, \& Varrot A (2017) Biophysical characterization and structural determination of the potent cytotoxic Psathyrella asperospora lectin. Proteins 85(5):969-975.

13. Bonnardel F, Kumar A, Wimmerova M, Lahmann M, Perez S, Varrot A, Lisacek F, \& Imberty A (2019) Architecture and evolution of blade assembly in beta-propeller lectins. Structure 27(5):764-775.

14. Machon O, Baldini SF, Ribeiro JP, Steenackers A, Varrot A, Lefebvre T, \& Imberty A (2017) Recombinant fungal lectin as a new tool to investigate O-GlcNAcylation processes. Glycobiology 27(2):123-128.

15. Liu W, Han G, Yin Y, Jiang S, Yu G, Yang Q, Yu W, Ye X, Su Y, Yang Y, Hart GW, \& Sun H (2018) AANL (Agrocybe aegerita lectin 2) is a new facile tool to probe for OGlcNAcylation. Glycobiology 28(6):363-373. 